\title{
ANALISIS PENGARUH CAPITAL ADEQUACY RATIO (CAR), NON PERFORMING LOAN (NPL), LOAN TO DEPOSIT RATIO (LDR), DAN SUKU BUNGA KREDIT KONSUMSI TERHADAP PENYALURAN KREDIT PEMILIKAN RUMAH (KPR) BANK BTN
}

Reza Christiamanah Agatha (1) Wiwin Priana (2) UPN “Veteran” Jawa Timur| rezaagatha@gmail.com (1)

Abstrak : Dalam penelitian ini data yang digunakan adalah data sekunder berupa data berkala (time series data) dalam periode tahun 2009-2018, data tersebut dianalisa dengan menggunakan program olah data statistik SPSS (Statistical Product and Sevice Solution) versi 13.0 analisa regresi liniear berganda. Kesimpulan dari penelitian ini yakni secara simultan variabel Capital Adequacy Ratio (CAR), Non Performing Loan (NPL), Loan to Deposit Ratio (LDR), dan Suku Bunga Kredit Konsumsi berpengaruh terhadap penyaluran Kredit Pemilikan Rumah (KPR) Bank BTN. Sedangkan secara parsial atau secara individual variabel Non Performing Loan (NPL) dan Suku Bunga Kredit Konsumsi berpengaruh terhadap penyaluran Kredit Pemilikan Rumah (KPR) Bank BTN, sedangkan Capital Adequacy Ratio (CAR) dan Non Performing Loan (NPL) tidak berpengaruh secara signifikan terhadap penyaluran Kredit Pemilikan Rumah (KPR) Bank BTN.

Keywords: Capital Adequacy Ratio (CAR), Non Performing Loan (NPL), Loan to Deposit Ratio (LDR), dan Suku Bunga Kredit Konsumsi dan KPR BTN 


\section{Pendahuluan}

Pemenuhan akan kebutuhan rumah merupakan kebutuhan primer yang harus dipenuhi selain kebutuhan akan pangan (makanan), sandang (pakaian), kesehatan dan pendidikan. Pemenuhan akan kebutuhan rumah merupakan salah satu faktor terpenting yang menentukan seseorang untuk membangun dan mengembangkan karakter maupun kepribadian seseorang. Namun di era saat ini pertumbuhan penduduk kian meningkat dan lahan pemukiman terbatas menjadi salah satu permasalahan yang kompleks apalagi jika berada di kota besar atau di pusat kota.

Menyadari permasalahan tersebut, industri perbankan mulai mengembangkan produknya untuk kebutuhan masyarakat dalam memenuhi kebutuhan akan rumah melalui produk Kredit Pemilikan Rumah (KPR) guna untuk membeli rumah baru maupun untuk renovasi rumah yang sesuai dengan beberapa produk yang ditawarkan bank. Pada umunya, perbankan di Indonesia cenderung lebih mengandalkan pendapatan bunga kredit atau yang bisa disebut dengan fee based income guna sebagai pemasukan dalam biaya operasionalnya.

Ada beberapa kredit yang ditawarkan bank salah satunya adalah Kredit Pemilikan Rumah (KPR) pada Bank Tabungan Negara. Bank Tabungan Negara merupakan salah satu pelopor pertama perbankan di Indonesia yang menghadirkan Kredit Pemilikan Rumah (KPR) dengan penawaran tenor hingga 25 tahun dengan angsuran sesuai dengan kapasitas atau kemampuan calon nasabah melalui beberapa produk yang ditawarkan dengan beberapa persyaratan yang harus dipenuhi calon nasabah. Sehingga tidak asing lagi jika Bank BTN merupakan salah satu perusahaan persero atau BUMN (Badan Usaha Milik Negara) yang mempunyai konsentrasi penuh dalam pengembangan bisnis perumahan di Indonesia melalui dukungan KPR BTN. 
Terkonsentrasinya usaha Bank BTN dalam menyalurkan Kredit Pemilikan Rumah (KPR) tidak terlepas dari permasalahan atau risiko kredit yang dihadapi dalam dunia perbankan. Kegiatan pemberian kredit ini memberikan pemberian yang tinggi dengan risiko yang tinggi pula. Untuk menghindari atau meminimalisir penyimpangan pemberian Kredit Pemilikan Rumah sebagaimana mestinya, pihak bank harus menyusun kebijaksanaan serta menganalisis calon nasabah secara terarah dengan prinsip kehati-hatian.

Tingginya risiko dalam pemberian Kredit Pemilikan Rumah dapat mempengaruhi bank dalam menyalurkan kredit yang diberikan kepada calon nasabah dengan sangat hati-hati. Pada teorinya, besarnya kredit yang disalurkan akan menentukan keuntungan atau pendapatan yang diperoleh oleh bank. Akan tetapi tidak berarti besarnya kredit yang disalurkan akan menentukan keuantungan yang diperoleh bank. Sehingga perlu dikaji ulang kebijakan pemberian kredit dan penilaian terhadap calon nasabah untuk meminimalisir tingkat risiko kredit bermasalah yang mempengaruhi kesehatan bank.

Kebutuhan masyarakat akan Kredit Pemilikan Rumah (KPR) ini harus diimbangi dengan kemampuan bank dalam menyalurkan kredit kepada masyarakat. Hal ini dikarenakan untuk menjaga kestabilan keuangan suatu bank. Oleh karena itu, bank harus memperhatikan beberapa faktor atau rasio yang dapat mempengaruhi penyaluran Kredit Pemilikan Rumah (KPR). Berdasarkan uraian latar belakang di atas, maka dibuat rumusan masalah sebagai berikut :

1. Apakah ada pengaruh antara Capital Adequacy Ratio (CAR), Non Performing Loan (NPL), Loan to Deposit Ratio (LDR), dan Suku Bunga Kredit Konsumsi terhadap penyaluran Kredit Pemilikan Rumah (KPR) Bank BTN?

2. Apakah ada variabel yang paling dominan terhadap penyaluran Kredit Pemilikan Rumah (KPR) Bank BTN? 


\section{Landasan Teori}

1. Teori Ekonomi Permintaan dan Penawaran

\section{A. Permintaan}

Teori permintaan menerangkan tentang sifat permintaan para pembeli terhadap suatu barang atau suatu kebutuhan. Teori permintaan menerangkan tentang ciri-ciri hubungan antara jumlah permintaan dan harga. Adapun hukum permintaan adalah semakin rendah harga suatu barang maka semakin banyak permintaan terhadap barang tersebut dan sebaliknya apabila semakin tinggi harga suatu barang tersebut maka semakin sedikit permintaan terhadap barang tersebut

B. Penawaran

Penawaran adalah jumlah barang yang produsen ingin tawarkan atau jual pada berbagai tingkat harga selama satu periode waktu tertentu. Hukum penawaran " semakin tingi harga suatu barang, semakin banyak jumlah barang tersebut akan ditawarkan oleh para penjual. Sebaliknya, semakin rendah harga suatu barang, semakin sedikit jumlah barang tersebut yang ditawarkan".

\section{Pengertian Bank dan Kredit}

Menurut Undang-undang RI nomor 10 tahun 1998 tanggal 10 November 1998 tentang perbankan, yang dimaksud bank adalah "Badan usaha yang menghimpun dana dari masyarakat dalam bentuk simpanan dan menyalurkan kepada masyarakat dalam bentuk kredit dan atau bentuk- bentuk lainnya dalam rangka meningkatkan taraf hidup rakyat banyak". Adapun beberapa pengertian bank menurut para ahli, Bank adalah lembaga keuangan yang kegiatan usahanya adalah menghimpun dana dari masyarakat dan menyalurkannya kembali dana tersebut ke masyarakat serta memberikan jasa-jasa bank lainnya.(Kasmir, 2002:02). Dalam fungsi bank sebagai lembaga intermediate, pada umunya perbankan di Indonesia 
mengandalkan pendapatannya melalui kredit yang disalurkan. Menurut Undang-Undang No.10 Tahun 1998, "Kredit" adalah uang atau tagihan yang dapat dipersamakan dengan itu, berdasarkan persetujuan atau kesepakatan pinjam meminjam antar bank dengan pihak lain yang mewajibkan pihak peminjam melunasi hutangnya setelah jangka waktu tertentu dengan pemberian bunga. Dari pengertian tersebut bahwa yang dapat disimpulkan kredit merupakan kesepakatan antar bank (kreditur) dengan nasabah penerima kredit (debitur) dengan perjanjian yang telah dibuat mencakup hak dan kewajiban.

\section{Pengertian Kredit Pemilikan Rumah (KPR)}

KPR (Kredit Pemilikan Rumah) merupakan kredit yang diberikan oleh bank kepada nasabah untuk pembelian rumah. Namun pada perkembangannya oleh pihak perbankan fasilitas KPR saat ini dikembangkan menjadi fasilitas kredit yang juga dapat digunakan untuk keperluan renovasi. (konsumen.ojk.go.id)

\section{Capital Adequacy Ratio (CAR)}

Capital Adequacy Ratio (CAR) merupakan rasio keuangan yang mengukur tingkat kecukupan modal perbankan. Menurut (Anindita:2011) semakin tinggi nilai CAR maka semakin besar pula daya financial yang dapat digunakan untuk keperluan pengembangan usaha dan untuk mengantisipasi potensi kerugian yang diakibatkan oleh penyaluran kredit. Secara singkat besarnya nilai CAR akan meningkatkan kepercayaan diri perbankan dalam menyalurkan kredit. Menurut peraturan Bank Indonesia Nomor: 8/18/PBI/2006, bank wajib menyediakan modal minimum sebesar $8 \%$ dari aktiva tertimbang menurut resiko yang dinyatakan dalam rasio Capital Adequacy Ratio (CAR) ini pada prinsipnya adalah bahwa setiap bentuk penanaman dalam bentuk kredit yang mengandung resiko maka harus 
disediakan sejumlah modal disesuaikan dengan presentase tertentu sesuai jumlah penanamannya.

\section{Non Performing Loan (NPL)}

Dalam pemberian kredit, bank akan dihadapkan pada resiko kredit yang tidak mampu dibayar oleh nasabah sehingga menimbulkan kredit bermasalah bahkan kredit macet. Non Performing Loan (NPL) adalah salah satu indikator yang mengukur perbandingan kredit yang tidak dapat dikembalikan oleh debitur alias "kredit macet", dengan total kredit yang disalurkan bank ke masyarakat. Semakin kecil NPL maka semakin kecil pula resiko kredit yang ditanggung oleh pihak bank. Praktisi perbankan menyepakati bahwa batas aman dari NPL suatu bank tidak boleh melebihi dari 5\%.

\section{Loan to Deposit Ratio (LDR)}

Menurut (Kasmir,2014) LDR (Loan to Deposit Ratio) adalah rasio yang digunakan untuk mengukur komposisi jumlah kredit yang diberikan dibanding dengan jumlah dana masyarakat dan modal sendiri. Dari pengertian LDR, maka dapat disimpulkan bahwa LDR adalah rasio yang mengukur sejauh mana kemampuan bank dalam membayar kembali penarikan dana yang dilakukan dengan mengandalkan kredit yang diberikan sebagai sumber likuiditasnya. Semakin tinggi rasio ini semakin rendah likuiditas bank yang bersangkutan. Namun sebaliknya, jika semakin rendah rasio LDR maka semakin tinggi likuiditas bank yang bersangkutan. Menurut Kasmir (2014), batas aman dari LDR suatu bank adalah sekitar $80 \%$, batas maksimal LDR dalah $110 \%$. Adapun rumus untuk menghitung LDR sebagai berikut :

\section{Suku Bunga Kredit Konsumsi}

Suku bunga kredit konsumsi merupakan catatan suku bunga yang ditetapkan selama satu bulan sekali dengan 
mempertimbangkan kondisi perekonomian baik di Indonesia maupun secara global, suku bunga kredit konsumsi rata-rata ini digunakan sebagai penentu suku bunga yang dipakai sebagai acuan atau standar pada pengelompokkan kredit konsumsi dari olahan audit OJK (Otoritas Jasa Keuangan). Acuan suku bunga kredit konsumsi ini tercatat pada pada website BPS (Badan Pusat Statistik), dimana pencatatan suku bunga kredit ini dikelompokkan secara khusus diantaranya suku bunga kredit konsumsi, suku bunga kredit investasi, dan suku bunga kredit modal kerja. Biasanya bank memiliki program khusus dalam penawaran suku bunga untuk menjual produk dan bersaing dengan bank-bank lain melalui suku bunga dasar kredit.

\section{Metode Penelitian}

Teknik yang digunakan dalam pengumpulan data pada penelitian ini adalah metode dokumentasi data sekunder yang diperoleh dari laporan keuangan tahunan (Annual Report) dari instansi-instansi terkait sesuai dengan data yang dibutuhkan. Metode pengumpulan data dalam penelitian ini dengan mengunduh data kuantitatif terkait, berupa data sekunder yang didapatkan dari website laporan keuangan tahunan Annual Report PT. Bank Tabungan Negara (Persero) dan website Badan Pusat Statistik (www.bps.go.id) periode tahun 2009- 2018.

Untuk menganalisis antar variabel, penelitian ini menggunakan metode regresi liniear berganda yaitu dengan menguji pengaruh ataupun keterkaitan antara variabel bebas (independent independent) yang jumlahnya lebih dari dua variabel terhadap variabel terikat (dependent variable) dengan menggunakan aplikasi SPSS (Statistical Product and Service Solutions) versi 13 pada Windows. asumsi klasik guna untuk mendapatkan hasil yang baik (Ghozali:2005). 
Dalam melaksanakan operasioanal regresi liniear tersebut ada 3 (tiga) asumsi dasar yang harus dipenuhi dan tidak boleh dilanggar, yaitu :

1. Tidak boleh terjadi autokorelasi

2. Tidak boleh terjadi multikolinieritas

3. Tidak boleh terjadi heterokedastisitas

\section{Pembahasan}

\section{A. Uji Asumsi Klasik}

Uji Asumsi Klasik adalah syarat- syarat yang harus dipenuhi sebelum dilakukan analisis regresi. Sehingga uji metode ini digunakan untuk menduga apakah terdapat masalah terhadap masing-masing variabel dan untuk mendapatkan hasil yang baik. Ada beberapa uji dalam uji asumsi klasik diantaranya, uji multikolinieritas, uji heterokedastisitas, dan uji autokorelasi. Uji normalitas adalah sebuah uji yang dilakukan dengan tujuan untuk menilai sebaran data pada sebuah kelompok data atau variabel, apakah sebaran data tersebut berdistribusi normal atau tidak ( I Gede Oggy,2015:7). Dalam uji normalitas ada beberapa metode, namun dalam penelitian ini menggunakan salah satu metode yaitu menggunakan metode uji KolmogorovSmirnov dengan melihat tingkat signifikansi 5\%. Dasar pengambilan keputusan dalam uji normalitas kolmogorovsmirnov ini dengan melihat probabilitas asymp.sig (2tailed) > 0,05 maka data memiliki distribusi normal dan sebaliknya. 


\section{Uji Normalitas}

Uji normalitas yang dilakukan dalam penelitian ini adalah uji statistik non-parametic Kolomogorov Smirnov (uji K-S).

Tabel 1. Hasil Uji Normalitas

\begin{tabular}{|ll|r|}
\hline & & \multicolumn{1}{|c|}{$\begin{array}{c}\text { Unstandardized } \\
\text { Residual }\end{array}$} \\
\hline $\mathrm{N}$ & Mean & 10 \\
Normal Parameters &, 0000000 \\
Most Extreme Differences & Std. Deviation & 4154,49126198 \\
& Absolute &, 207 \\
& Positive &, 132 \\
& Negative &,- 207 \\
Kolmogorov-Smirnov Z & &, 654 \\
Asymp. Sig. (2-tailed) & &, 786 \\
\hline
\end{tabular}

Dari hasil uji normalitas memunjukkan bahwa besarnya nilai signifikan 0,786 yang berarti lebih dari 0,05. Dengan demikian data dalam penelitian ini dinyatakan terdistribusi normal.

2. Uji Multikolinieritas

Menurut (Gunawan, 2003:281) multikolinieritas adalah hubungan yang kuat antara satu variabel bebas dengan variabel bebas lainnya dalam sebuah model regresi. Multikolinieritas adalah terjadinya hubungan linier antara variabel bebas dalam suatu model Regresi Linier Berganda (Gujarati, 2004). Dari hasil uji multikolinieritas dapat diketahui bahwa semua variabel bebas memiliki nilai Tolerance lebih dari 0,10 dan nilai VIF kurang dari 10 . Sehingga dapat disimpulkan bahwa dalam penelitian ini tidak terjadi gejala multikolinieritas. 


\section{Uji Heterokedastisitas}

Uji heterokedastisitas bertujuan untuk menguji apakah suatu model regresi terjadi ketidaksamaan varian dan residual pada model regresi linear. Dalam penelitian uji heterokedastisitas ini dilakukan dengan metode uji Spearman Rho, dengan ketentuan uji 2 sisi. Jika nilai sig > 0,05 maka dapat dikatakan terbebas dari gejala heterokedastisitas. Sebaliknya, jika nilai sig $<0,05$ maka varian tersebut ada gejala heterokedastisitas. Dari uji Spearman Rho menunjukkan bahwa nilai signifikansi variabel CAR sebesar 0,777, variabel NPL 0,803, variabel LDR 0,467, dan variabel Suku Bunga Kredit Konsumsi 0,829. Sehingga dapat disimpulkan bahwa semua variabel memiliki nilai signifikan lebih dari 0,05 terhadap ABS_RES atau Unstandardized Residual. Artinya dapat disimpulkan bahwa penelitian ini terbebas dari gejala heterokedastisitas.

\section{Uji Autokorelasi}

Uji autokorelasi bertujuan untuk mengetahui adanya korelasi antara anggota serangkaian variabel ada didalam model prediksi dengan perubahan waktu. Untuk mengetahui ada atau tidaknya autokorelasi dapat dilakukan dengan D-W Test. Dari hasil Durbin Watson menunjukkan bahwa nilai DW sebesar 1,290 dengan jumlah sampel (n) sebesar 10 dan jumlah jumlah variabel independen (k) sebesar 4, sehingga didapatkan nilai $\mathrm{dL}$ sebesar 0,3760 dan nilai $\mathrm{dU}$ sebesar 2,4137. Jika dimasukkam kedalam rumus deteksi autokorelasi positif $\mathrm{dL}<\mathrm{dw}<\mathrm{dU}$, maka akan dihasilkan nilai sebagai berikut $0,3760<1,290<2,4137$. Sehingga nilai D-W terletak didaerah keragu-raguan tetapi masih bisa ditoleransi sehingga penelitian masih bisa dilanjutkan. 


\section{B. Uji Regresi Linear Berganda Uji Koefisien Determinasi}

Koefisien determinasi $\left(R^{2}\right)$ atau bisa dikatakan nilai koefisien determinasi atau $\mathrm{R}$ Square ini digunakan untuk memprediksi seberapa besar kontribusi pengaruh yang diberikan variabel $\mathrm{X}$ secara simultan terhadap variabel $\mathrm{Y}$. Berdasarkan nilai R Square menunjukkan 0,916 atau 91,6\%. Hal ini menunjukkan bahwa 91,6\% variabel penyaluran Kredit Pemilikan Rumah dapat dijelaskan oleh variabel CAR, NPL, LDR, dan Suku Bunga Kredit Konsumsi sedangkan $8,4 \%$ ditentukan oleh faktor lain di luar model yang diteliti $(100 \%-91,6 \%=8,4 \%)$.

\section{Tabel 2. Hasil Uji F}

\begin{tabular}{|c|c|c|c|}
\hline Model & Sum of Squares & $\mathrm{F}$ & Sig. \\
\hline $\begin{array}{ll}1 & \text { Regression } \\
& \text { Residual } \\
\text { Total }\end{array}$ & $\begin{array}{r}1686999760,087 \\
155338178,813 \\
1842337938,900\end{array}$ & 13,575 &, $007^{\mathrm{a}}$ \\
\hline
\end{tabular}

Berdasarkan hasil regresi pada tabel 2 meunjukkan bahwa nilai $\mathrm{F}$ hitung lebih besar dari $\mathrm{F}$ tabel atau nilai signifikansi sebesar 0,007 yakni kurang dari 0,05. Hal ini menunjukkan bahwa model regresi fit layak digunakan dalam penelitian terhada penyaluran Kredit Pemilikan Rumah (KPR).

Hasil regresi dalam penelitian ini mennjukkan bahwa variabel CAR bersifat positif dan tidak berpengaruhcsecara signifikan terhadap penyaluran KPR. Hal ini ditunjukkan dengan besarnya nilai signifikansi CAR sebesar $(0,073)>\alpha=$ $(0,05)$. Peneltian ini sejalan dengan penelitian yang dilakukan oleh Achmad (2019) alasan tidak berpengaruhnya CAR terhadap penyaluran KPR dimungkinkan bank lebih memilih untuk memperkokoh struktur modalnya daripada 
mengalokasikan kedalam penyaluran Kredit Pemilikan Rumah (KPR).

Dalam penelitian ini NPL dinyatakan berpengaruh secara signifikan terhadap penyaluran KPR. Hal ini ditunjukkan dengan besarnya nilai signifikansi NPL sebesar $(0,014)<\alpha=(0,05)$. Indikator risiko kredit macet dapat diukur dengan NPL, semakin tinggi tingkat NPL maka semakin tinggi risiko dan semakin buruk kualitas kredit yang dihadapi bank salahsatunya adalah risiko tidak terbayarnya pengembalian kredit atau bisa disebut juga dengan kredit macet. Hasil penelitian ini sejalan dengan penelitian yang dilakukan oleh Achmad (2019) yang menyatakan bahwa NPL berpengaruh terdahadap penyaluran kredit.

Hasil regresi dalam penelitian ini mennjukkan bahwa variabel LDR bersifat positif dan tidak berpengaruh secara signifikan terhadap penyaluran KPR. Hal ini ditunjukkan dengan besarnya nilai signifikansi $\operatorname{LDR}$ sebesar $(0,0147)>\alpha=$ $(0,05)$. Hasil penelitian ini mendukung teori yang dikemukakan oleh Lukman Dendawijaya (2005:118) yaitu semakin tinggi rasio LDR maka semakin rendah pula kemampuan likuiditas bank, sehingga manajemen bank harus mempetimbangkan terlebih dahulu dalam menyalurkan dana yang dimiliki.

Hasil regresi dalam penelitian ini mennjukkan bahwa variabel Suku Bunga Kredit Konsumsi bersifat negatif dan berpengaruh secara signifikan terhadap penyaluran KPR. Hal ini ditunjukkan dengan besarnya nilai signifikansi suku bunga kredit konsumsi sebesar $(0,006)>\alpha=(0,05)$. Penelitian ini sejalan dengan penelitian yang dilakukan oleh Piani (2018) menyatakan bahwa suku bunga kredit konsumsi berpengaruh secara signifikan terhadap penyaluran kredit pemilikan rumah. Bertolak dengan hasil penelitian yang diteliti oleh Siswati (2015) bahwa tingkat suku bunga kredit bersifat positif dan tidak signifikan terhadap penyaluran kredit. 


\section{Penutup}

1. Capital Adequacy Ratio (CAR) tidak berpengaruh secara signifikan terhadap penyaluran Kredit Pemilikan Rumah (KPR), yang artinya setiap penurunan maupun peningkatan Capital Adequacy Ratio tidak berpengaruh terhadap penyaluran Kredit Pemilikan Rumah. Hal ini dikarenakan bank ingin tetap mempertahankan modalnya agar tingkat prosentase Capital Adequacy Ratio sesuai dengan ketentuan peraturan Bank Indonesia yakni minimal $8 \%$.

2. Non Performing Loan (NPL) berpengaruh terhadap penyaluran Kredit Pemilikan Rumah (KPR). Non Performing Loan ini berguna sebagai indikator untuk melihat efektifitas bank terhadap kredit macet, semakin tinggi rasio ini maka semakin rendah penyaluran kredit dan begitu juga sebaliknya. Sehingga, dalam penyaluran Kredit Pemilikan Rumah bank harus memiliki kebijakan dalam menilai nasabah untuk meminimalisir tidak terbayarnya pengembalian kredit atau yang bisa disebut juga dengan kredit macet.

3. Loan to Deposit Ratio (LDR) tidak berpengaruh secara signifikan terhadap Kredit Pemilikan Rumah (KPR). Hal ini dikarenakan tingkat LDR dalam 10 tahun terakhir mengalami peningkatan dari minimal yang telah ditentukan oleh Bank Indonesia, tingginya jumlah kredit yang disalurkan dan disertai dengan pertumbuhan DPK yang kian melambat.

4. Suku bunga kredit konsumsi berpengaruh terhadap penyaluran Kredit Pemilikan Rumah (KPR). Dalam teorinya, semakin tinggi tingkat suku bunga kredit maka semakin rendah permintaan akan kredit, begitu juga sebaliknya semakin rendah tingkat suku bunga kredit maka semakin tinggi permintaan akan kredit karena hal 
ini berpengaruh pada jumlah kredit yang disalurkan. Dalam penelitian ini variabel X4 berpengaruh pada penyaluran Kredit Pemilikan Rumah (KPR) dikarenakan dalam penelitian ini menggunakan total keseluruhan Kredit Pemilikan Rumah yang disalurkan, berbeda dengan penelitian sebelumnya hasil uji $t$ tidak berpengaruh karena penelitian yang diteliti hanya dalam sub tipe Kredit Pemilikan Rumah.

\section{Daftar Referensi}

Anindita, I. 2011. Analisis Pengaruh Tingkat Suku Bunga, CAR, NPL, dan LDR Terhadap Penyaluran Kredit UMKM (Studi Pada Bank Umum Swasta Nasional Periode 2003-2010). Universitas Diponegoro

Fran, Ahmad. 2017. Pengaruh Capital Adequacy Ratio dan Loan to Deposit Ratio Terhadap Penyaluran Kredit Pada Bank Rakyat Indonesia Tbk. JOM Fekon, Vol. 4No. 1 (Februari) 2017.

Gede, I dan Surya Dewi. 2015. Pengaruh DPK, BI RATE, dan NPL Terhadap Penyaluran Kredit Modal Kerja Pada BPR di Provinsi Bali Tahun 2009- 2014. Fakultas Ekonomi dan Bisnis Universitas Udayana. Bali.

Kadek, Putu, dan Made. 2017. Analisis Pengaruh Capital Adequacy Ratio (CAR), Dana Pihak Ketiga (DPK), Suku Bunga Bank Indonesia (BI Rate), Non Performing Loan (NPL) Dan Tingkat Inflasi Terhadap Penyaluran Kredit Kepimilikan Rumah (KPR) Komersial (Studi Pada BPD Bali Periode 2003-2017). Universitas Pendidikan Ganesha. 
Kasmir, 2010. Manajemen Perbankan. Ed. Revisi, 9. Jakarta : PT RAJAGRAFINDO PERSADA.

Kasmir. 2012. Bank dan Lembaga Kuangan Lainnya. Jakarta: PT RAJAGRAFINDO PERSADA.

Lusia,, Saryadi, dan Andi. 2014. Pengaruh Capital Adequacy Ratio (CAR), Loan to Deposit Ratio (LDR), Non Performing Loan (NPL), Return On Assets (ROA), Net Interest Margin (NIM), Dan Biaya Operasional Pendapatan Operasional Terhadap Pemberian Kredit. (Studi Kasus Pada BPR BKK Pati Kota Periode 2007-2012). Diponegoro Journal Social And Politic. Universitas Diponegoro.

Ni Made Inten Uthami Putri Warsa dan I Ketut Mustanda. 2016. Pengaruh CAR, LDR, NPL Terhadap ROA Pada Sektor Perbankan di Bursa Efek Indonesia. Fakultas Ekonomi dan Bisnis Universitas Udayana.

Pamularsih, D. 2015. Pengaruh LDR, NPL, NIM, BOPO, CAR, dan Suku Bunga Terhadap Profitabilitas Pada Sektor Perbankan Yang Terdaftar di Bursa Efek Indonesia Periode 2009-2013. Jurnal Akuntansi Fakultas Ekonomi Universitas Pandanaran Semarang.

Said P. 2018. Pengaruh Suku Bunga Kredit Konsumsi, Inflasi, NPL, Dan LDR Terhadap Penyaluran Kredit Kepemilikan Rumah Pada Bank Perkreditan Rakyat Di Indonesia Tahun 2012- 2015. Universitas Tanjungpura.

Semadiasri, Ketut. Dkk. 2015. Analisis Pengaruh CAR, NPL, dan Tingkat Inflasi Terhadap Penyaluran Kredit Kepemilikan Rumah (KPR) (Studi Pada BPD Bali Periode 2011-2013). Singaraja. 